\title{
EMPIRICAL ANALYSIS OF AWARENESS AND ADOPTION OF PADDY PRODUCTION TECHNOLOGIES IN THIRUVANNAMALAI DISTRICT
}

\author{
M. NIRMALA DEVI ${ }^{1}$, S. SELVANAYAKI ${ }^{2}$, M. GOPI ${ }^{3} \&$ R. T. NIVITHA SHREE ${ }^{4}$ \\ ${ }^{1}$ Associate Professor, (Agrl. Extension) Department of Agrl. Extension and Rural Sociology, TNAU, Coimbatore, India \\ ${ }^{2}$ Assistant Professor, (ARM) Department of Social Sciences. Forestry College and Research Institute, Mettupalayam, India \\ ${ }^{3,4}$ Project Students, Agricultural College and Research Institute, Vazhavachanur, India
}

ABSTRACT
Tamil Nadu is one of the biggest producers of Paddy. The major food crop paddy is grown wide because rice is the staple
food of the state. High variability exists in rice yields across the state. The yield variations indicate that there exists
always a need to tap the high yields with productive growth parameters. Therefore the present study was taken up with
the objectives of analysing the awareness, adoption and reasons for low yield in paddy crop in Thandrampattu block of
Thiruvannmalai District. Five villages from Thandrampattu block viz., Pudurchekkadi, Perungolathur, Sathanoor,
Radhapuram and Chinniyampettai were taken for the study. The sample size consists of 60 farmers.
While analysing the results it is observed that the variety is ADT - 43, for that the season is well known and majority of
the farmers adopting the practice of sowing in correct season (91.67 per cent) and 33.67 per cent of farmers were not
practicing the seed treatment technology. Majority of the farmers are not strictly adhering to the recommended age of
seedlings (91.67). Spacing for the growing of paddy is also least concerned (80 per cent) by the respondents and 50 per
cent of the paddy farmers only know the benefits of crop rotation. Further it is observed that non-availability of HYV
seeds and using of age old seedlings were the reasons for low yield in paddy.
The low yield or the bridgeable yield gap could be addressed through ensuring the availability of HYV seeds at proper
time, conducting mass awareness campaign on latest production technologies in paddy, organizing method
demonstration and result demonstration in farmer's holdings with HYV and latest production technologies and
creating facilities to have quicker access to critical inputs at right time.
KEYWORDS: Awareness \& Adoption in Paddy Production Technologies

Received: Sep 29, 2020; Accepted: Oct 19, 2020; Published: Nov 09, 2020; Paper Id.: IJASRAUG202033

\section{INTRODUCTION}

Tamil Nadu is one of the biggest producers of paddy. The state is historically known for its agriculture from ancient times. The major food crop paddy is grown wide because rice is the staple food of the state. But there exists a high variability in rice yields across the state. The rice growers still observing the age-old practices instead of new interventions. The potential of varieties are always enhanced by the precise technologies adopted by the farmers in raising the crop. The awareness plays a major role in adopting any technology with the scope of gaining more returns. In paddy production technologies there exist inventions from the variety sown to harvest of the crop. The awareness and adoption level of the paddy growers are always influenced by their profile characteristics. As the awareness improves the adoption rate will also automatically influenced. This will lead to meet out the yield variations in the paddy crop and enhance the crop to attain its potential yield. 
With this view, this study on awareness and adoption of paddy production technologies in Thiruvannamalai District in was taken up with the following objectives.

\section{Specific Objectives}

- To analyse the profile characteristics of paddy growers.

- To ascertain the Awareness and adoption levels of paddy growers on paddy cultivation

- To analyse the reasons for low yield in paddy crop.

\section{METHODOLOGY}

Agriculture and silk saree weaving are the major two enterprises in Thiruvannamalai District. More than one lakh hectares of land is under paddy cultivation in the District. In Thiruvannamalai, there are 12 taluks. Among them we have purposefully selected the Thandarampattu taluk where the major crop cultivated is paddy. There are forty-seven revenue villages in Thandarampattu block. Among these, five villages of having more area under paddy cultivation were selected. The selected villages were Pudurchekkadi, Perungolathur, Sathanoor, Radhapuram and Chinniyampettai.

A well-structured interview schedule was prepared and pre tested among the farmers and data were collected from the paddy growers. The independent variables identified for the study were measured using scoring procedures.

\section{FINDINGS AND DISCUSSION}

\section{Profile Characteristics of Paddy Growers}

In social science, it is essential to know about the farmer's characteristics which would serve as a base for clear and thorough understanding about the background of farmers. The information about these characteristics would help us for deriving exact results for data correlation. In the study it is observed that large number of respondents were having the secondary level of education (33.33 per cent) and having agriculture as their Primary occupation (73.33 per cent). It could be further observed that no members of the farmers were involved in social participation (70 per cent) and 33.33 per cent of farmers are having contact with extension agency and their purpose of contact is for agriculture alone (90 per cent). It also inferred that 93 per cent of the respondents never heard the radio, 21 per cent read the newspaper once in a week, 91.67 per cent of the farmers never read the magazine and 43.33 per cent of the farmers visited agricultural exhibition more than 3 in a year.

\section{Awareness and Adoption Level of Paddy Growers}

Table 1

\begin{tabular}{|c|l|c|c|c|c|}
\hline \multirow{2}{*}{ S. No } & \multicolumn{1}{|c|}{ Particulars } & \multicolumn{2}{c|}{ Aware } & \multicolumn{2}{c|}{ Adoption } \\
\cline { 3 - 5 } & & Aware & Un aware & Adopted & $\begin{array}{c}\text { Not } \\
\text { Adopted }\end{array}$ \\
\hline 1. & Season & 100 & 0.00 & 91.67 & 8.33 \\
\hline 2. & Varieties /Hybrids & 100 & 0.00 & 100 & 0.00 \\
\hline 3. & Seed treatment with bio inoculants & 73.33 & 26.67 & 33.33 & 66.67 \\
\hline 4. & 15 days- transplanting & 86.67 & 13.33 & 08.33 & 91.67 \\
\hline 5. & Machine transplanting & 98.33 & 01.67 & 15.00 & 85.00 \\
\hline 6. & Spacing & 98.33 & 01.67 & 20.00 & 80.00 \\
\hline 7. & Seedling per hill & 93.33 & 06.67 & 38.33 & 61.67 \\
\hline 8. & Intermittent irrigation & 90.00 & 10.00 & 25.00 & 75.00 \\
\hline
\end{tabular}




\begin{tabular}{|c|l|c|c|c|c|}
\hline 9. & $\begin{array}{l}\text { Recommended dose of fertilizer } \\
\text { application: 150:50:50 NPK kg/ha }\end{array}$ & 56.00 & 44.00 & 18.33 & 81.67 \\
\hline 10. & Micronutrient spray & 48.33 & 51.67 & 25.00 & 75.00 \\
\hline 11. & Conoweeding & 66.67 & 33.33 & 08.33 & 91.67 \\
\hline 12. & Herbicide application & 93.33 & 06.67 & 28.33 & 71.67 \\
\hline 13. & IPM practices for pest and diseases & 95.00 & 05.00 & 25.00 & 75.00 \\
\hline 14. & LCC based fertilizer application & 13.33 & 86.67 & 00.00 & 100.00 \\
\hline 15. & Harvester ( Combined harvester) & 100.00 & 00.00 & 95.00 & 05.00 \\
\hline 16. & Crop rotation & 96.67 & 03.33 & 50.00 & 50.00 \\
\hline
\end{tabular}

Here, the variety is ADT - 43, for that the season is well known and majority of the farmers adopting the practice of sowing in correct season(91.67 per cent) and 33.67 per cent of farmers were not practicing the seed treatment technology. Majority of the farmers are not strictly adhering to the recommended age of seedlings (91.67). Spacing for the growing of paddy is also least concerned ( 80 per cent) by the respondents and 50 per cent of the paddy farmers only know the benefits of crop rotation.

\section{Reasons for Low Yield in Paddy Crop}

The farmers' responses against the reasons for low yield were counted as percentage and the results presented in Table 3.

Table 2: Reasons for Low Yield in Paddy Crop

\begin{tabular}{|c|l|c|}
\hline S. No & \multicolumn{1}{|c|}{ Particulars } & Percent \\
\hline \multicolumn{2}{|c|}{ Technological Aspects } \\
\hline 1. & Non availability of suitable HYV seeds & 55.67 \\
\hline 2. & Using Age old seedlings & 29.00 \\
\hline 3. & Lack of information about pest and diseases & 12.33 \\
\hline 4. & Lack of awareness or knowledge of about certain technologies & 04.00 \\
\hline 5. & Lack of conviction in the new technology & 04.00 \\
\hline 6. & Micro nutrient deficiency in Soil & 02.00 \\
\hline \multicolumn{2}{|c|}{ Institutional Aspects } \\
\hline 7. & Extension agency contact at village level & 50.00 \\
\hline 8. & Unaware of services offered by the govt. & 50.00 \\
\hline \multicolumn{2}{|c|}{ Resources } & 43.33 \\
\hline 9. & Non-availability of seed at proper time & 20.00 \\
\hline 10. & Lack of irrigation facility & 16.00 \\
\hline 11. & High cost of fertilizers & 12.00 \\
\hline 12. & High cost of pesticides & 04.67 \\
\hline 13. & High cost of Labour & 04.00 \\
\hline 14. & Using own seeds for a number of years \\
\hline
\end{tabular}

It is observed from table 2, that under technological aspects non-availability of high yielding variety seeds (55.67 $\%)$, Using Age old seedlings (29.00\%) and lack of information about pest and diseases (12.33\%) were reported by the paddy growers as the reasons for low yield. Further, it is observed that weak extension activities at village level and lack of awareness on services offered by the Government are the institutional related constraints. Under resources, Nonavailability of seed at proper time and Lack of irrigation facility are the major constraints faced by the paddy growers.

\section{CONCLUSIONS}

The reasons for low yield in paddy could be addressed through ensuring the availability of good quality HYV seeds at proper time to the farmers, conducting mass awareness campaign on varieties and improved production technologies in paddy, organizing method demonstration and result demonstration in farmer's holdings and creating facilities to have access to critical inputs at right time. 


\section{REFERENCES}

1. Amandeep Kaur, Hardeep S Sabhikhi, Gurpreet Singh, Jaswinder Singh and Gurpreet Kaur. 2013. Yield Gap Analysis in Paddy Based on Demonstration on Seed Treatment Technique for Control of Bacterial Leaf Blight. Journal of Krishi Vigyan. 2 (1): 79-81.

2. Shashank, D., et al. "Comparative Analysis of Adoption of Nutrient Management Packages by Paddy Farmers of Nalgonda District." International Journal of Humanities and Social Sciences (IJHSS) 5.6, Oct - Nov 2016; 23-28

3. Lakshmi Thadi. 1992. Evaluation of impact of improved dryland agricultural technologies in the Maheswaram watershed development project in Ranga reddy district of Andhra Pradesh. Unpub. Ph. D. Thesis. AC \& RI, Killikulam.

4. Shashank, D., et al. "Constraints Perceived by the Paddy Farmers in Adoption of Nutrient Management Practicesin Nalgonda District of Telangana State." International Journal of Humanities and Social Sciences (IJHSS) 5.6, Oct - Nov 2016; 107-112

5. Hossain, M. and Fischer, K.S. 1995. Rice research for food security and sustainable agricultural development in Asia. GeoJournal 35 (3): 286-298.

6. Shivraj, P., and H. Philip. "Role of mass media in changing awareness level on climate change among small and marginal paddy farmers of Tamil Nadu." Int J Humanities and Soc Sci Interventions 5.4 (2016): 45-50.

7. Chakraborty, Samarpan, and S. K. Acharya. "Disillusionment, Dissonance and Entropy Amidst Indian Agriculture: The Reflection and Refraction." International Journal of Applied and Natural Sciences (IJANS) ISSN (P) (2018): 2319-4014. 